\title{
Shoot and root interference of morning glory on the initial growth of sugarcane
}

\author{
FELIPE C. ALVES, SILVANO BIANCO, MARILUCE P. NEPOMUCENO, \\ JOSÉ VALCIR F. MARTINS and PEDRO LUÍS C.A. ALVES
}

\author{
Laboratório de Plantas Daninhas/LAPDA, Departamento de Biologia Aplicada à Agropecuária, \\ Faculdade de Ciências Agrárias e Veterinárias, Universidade Estadual Paulista/UNESP, Via \\ de acesso Prof. Dr. Paulo D. Castellane, s/n, 14884-900 Jaboticabal, SP, Brazil
}

Manuscript received on April 30, 2016; accepted for publication on June 12, 2017

\begin{abstract}
Among weeds, morning glories comprise a very important group of climbing plants that infest sugarcane crops. The objective of this study was to evaluate the shoot and root interference of Merremia cissoides on the initial growth of sugarcane cultivar RB 966928. The experiment consisted of five treatment groups: (i) sugarcane monocropping, (ii) morning glory monocropping, (iii) sugarcane intertwined with morning glory but inseparate boxes, (iv) sugarcane intertwined with morning glory in attached boxes and (v) sugarcane with morning glory in attached boxes with morning glory prevented from intertwining with the sugarcane. The experimental design consisted of randomized blocks with four replicates. Merremia cissoides adversely affected the initial growth of the RB 966928 sugarcane starting at 90 days after transplanting (DAT). This effect increased with the time of intercropping, reaching at 180 DAT with a reduction of $57.3 \%$ in height, $15.5 \%$ in stalk diameter, $90.4 \%$ in leaf areas, 86.6 and $75.2 \%$ in stalk and leaf dry mass, respectively. These reductions primarily due to the weed intertwining with the sugarcane plants because the weed had a physical choking and shading effect. This negative effect of morning glory on the sugarcane plants increased when they shared the substrate (i.e., when they competed for space and water), which also adversely affected weed growth, reducing $50.2 \%$ leaf areas and $42.1 \%$ shoot dry mass. The leaf area and the stalk and leaf dry mass of sugarcane are the characteristics more sensitive to the weed interference. Thus, both the shoot and root of M. cissoides interferes negatively in the growth of sugarcane, with the effect proportional to the period of coexistence, highlighting the detrimental effect on the stem (greater economic interest), and may also compromise the mechanical harvesting of the crop.
\end{abstract}

Key words: Merremia cissoides, competition, Saccharum, methodology.

\section{INTRODUCTION}

Sugarcane (Saccharum spp.) is a major crop cultivated in Brazil. The sugarcane cultivation area covers approximately 9.1 million ha intended for

Correspondence to: Pedro Luís da Costa Aguiar Alves

E-mail: plalves@fcav.unesp.br sugar and ethanol production that accounts for an estimated production of 671.69 million tons (CONAB 2015), rendering this economic activity one of the most important in Brazil. The South-Central region is notable for sugarcane production, and the state of São Paulo is the largest producer, with $52 \%$ of the planted area (CONAB 2015). Due to the importance 
of sugarcane in Brazil, it is paramount that this crop be managed appropriately to increase or prevent a drop in production and/or yield.

A serious issue in sugarcane cropping is the presence of weeds in cultivated areas (Martinelli et al. 2011). Weeds compete intensely with crops for environmental resources, leading to a decrease in the number of stalks and a reduction in the yield and quality of the harvested product (technical characteristics) (Silva et al. 2009), among other effects. Thus, an enormous expenditure of financial resources is required for weed control. Furthermore, weeds may have other direct effects in addition to competition, including allelopathy and parasitism, and may also have an indirect effect by acting as hosts for pests and diseases, thereby depreciating the harvested product or affecting the crop management practices (Pitelli 1985).

Currently, the green harvesting system is adopted for sugarcane production. Sugarcane burning is no longer used prior harvesting, which minimizes the harmful effects on humans and the environment. Phytosociological studies conducted by Kuva et al. (2008) and Ferreira et al. (2011) showed that the weed communities of green sugarcane areas had changed. Species of the Ipomoea and Merremia genera (called morning glories) are important weeds (Raimúndez-Urrutia et al. 2008), especially in the green cane system.

Morning glories develop during the large growth phase of sugarcane fields and can compete with the crop, with a period prior to interference of Ipomoea varying from 33 to 76 days after emergence (Piza et al. 2016, Silva et al. 2009). Besides that, adult plants intertwine with the stalks and leaves to adversely affect plant growth (Azania et al. 2011), crop management practices and the harvest (Piza et al. 2016, Ferreira and Miotto 2013) (i.e., can cause indirect effects). Despite the lack of data on the effect of morning glories (especially Merremia cissoides) on the sugarcane growth and yield, their control is important and a concern.
Furthermore, $M$. cissoides is one of the morning glories that is most resistant to chemical control (Lucio et al. 2011, Perim et al. 2009, Wilson 2005).

Our hypothesis that sugarcane may exhibit substantially reduced initial growth in the presence of Merremia cissoides due to the direct and indirect effects of the weed is based on visual reports (Kuva et al. 2008, Ferreira et al. 2011). The objective of this study was to evaluate the shoot and root effects of $M$. cissoides on the initial growth of sugarcane and provide further evidence to devise an integrated weed management program for sugarcane plantations.

\section{MATERIALS AND METHODS}

The experiment was conducted using 64 cement boxes with a $125 \mathrm{~L}$ capacity $(0.5 \mathrm{~m} \times 0.5 \mathrm{~m} \times 0.5 \mathrm{~m})$ that werefilled with soil from the topsoil layer of a typical eutroferric Red Latosol with a clay texture, $\mathrm{pH} 5.9,21 \mathrm{~g} / \mathrm{dm}^{3}$ of organic matter, $54 \mathrm{mg} / \mathrm{dm}^{3}$ of $\mathrm{P}, 4.1 \mathrm{mmolc} / \mathrm{dm}^{3}$ of $\mathrm{K}, 60 \mathrm{mmolc} / \mathrm{dm}^{3}$ of $\mathrm{Ca}, 28$ mmolc/ $/ \mathrm{dm}^{3}$ of $\mathrm{Mg}$, and $82 \%$ base saturation (V).

The sugarcane cultivar RB 966928 was intercropped (or not) with morning glory (Merremia cissoides) using the following treatment strategies shown in Figure 1: (i) sugarcane monocropping, (ii) morning glory monocropping, (iii) sugarcane cropping intertwined with morning glory but in separate boxes, (iv) sugarcane cropping intertwined with morning glory in attached boxes and (v) sugarcane intercropping with morning glory in attached boxes with morning glory prevented from intertwining with the sugarcane. This treatment arrangement allowed each species to explore the same volume of soil and distinguished between the shoot (p.e., competition for light and space), and root interference (competition for water, nutrients, space, etc).

In treatments (ii), (iii), (iv) and (v), bamboo stakes were placed at the corners of the cement boxes to ensure that the morning glory would maintain its 


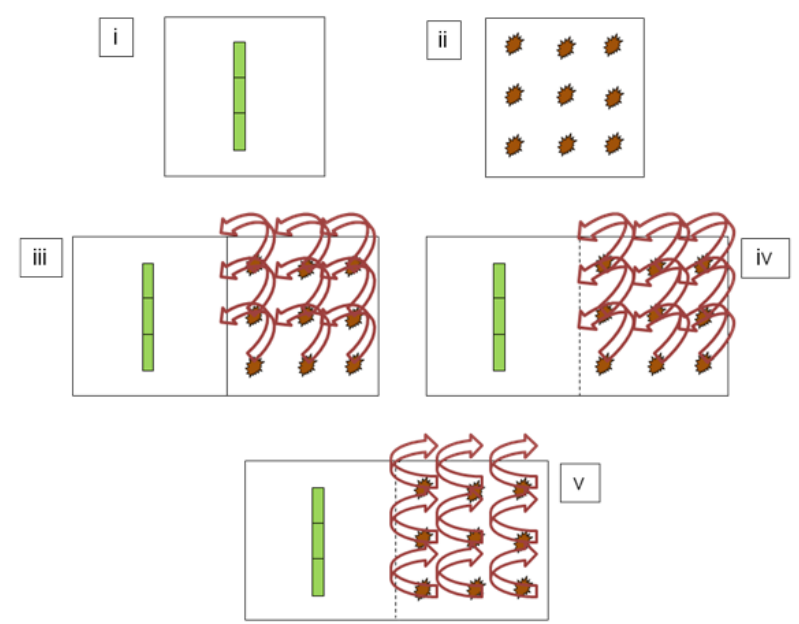

Figure 1 - Schematic diagram of the experimental treatments: (i) sugarcane monocropping, (ii) morning glory monocropping, (iii) sugarcane cropping intertwined with morning glory but in separate boxes, (iv) sugarcane cropping intertwined with morning glory but in attached boxes and (v) sugarcane intercropping with morning glory in attached boxes without intertwining with the sugarcane. The arrows indicate the growth direction of the morning glory plants.

climbing habit and take the direction that would hypothetically lead to the expected effect in each treatment without affecting the natural growth of the sugarcane or Merremia cissoides itself.

The sugarcane was planted on October 18, 2013 , by placing a cane sett with three healthy buds in the center of the box at a depth of $5 \mathrm{~cm}$. Morning glory seedlings were previously grown in polystyrene trays and transplanted when the sugarcane sprouted on October 29, 2013. Nine seedlings were transplanted per box, representing a density similar to that recorded by Silva et al. (2009) in the field. Nitrogen fertilization was performed 50 days after sugarcane planting using $200 \mathrm{~kg} \mathrm{ha}^{-1}$ of urea. A second top dressing fertilization was performed 75 days after sugarcane planting using the formulation 18-0-26 and $600 \mathrm{~kg} \mathrm{ha}^{-1}$.

The experimental design consisted of randomized blocks with 5 treatments and 4 replicates for each evaluation period 90 and 180 days after transplantation (DAT) of $M$. cissoides.

The stalk height and diameter of the sugarcane plants were evaluated monthly from 60 to 180
DAT. The following variables were assessed in the sugarcane and morning glory plants at 90 and 180 DAT: leaf area, green leaves (LI 3000 A area meter, LiCor), and shoot dry mass (leaves and stalks/stem). For this purpose, the plants were cut close to the soil surface, and the stalks and leaves (sugarcane) and stems and leaves (morning glory) were separated. The materials were dried in a forced-air oven at $70^{\circ} \mathrm{C}$ for 120 hours, after which the dry mass of the different plant parts of the crop and weed were assessed.

The absolute growth rate of all plant biometric characteristics was calculated using the data from the first and last evaluations according to the formula proposed by Benincasa (2004).

The data gathered in the evaluations were subjected to analysis of variance (ANOVA) using the $\mathrm{F}$ test.The means were compared using Tukey's test at 5\% probability (AgroEstat) and submitted to regression analysis (MicroCal Origin).

\section{RESULTS AND DISCUSSION}

No effect of intercropping with morning glory was observed on sugarcane plant heightand stalk diameters until 90 DAT (Figures 2 and 3). From 120 to $180 \mathrm{DAT}$, sugarcane plants that grew intertwined with morning glory in attached boxes (i.e., sharing the substrate- treatment iv) became $42.7 \%$ smaller and with the stem $15.5 \%$ narrower than the control plants (treatment i) and the plants intercropped with morning glory in attached boxes with weed intertwining prevented (treatment v). Conversely, sugarcane plants intercropped and intertwined with morning glory but in separate boxes (treatment iii) grew as tall as the control plants but were 33.9 $\%$ smaler than the plants from treatment $\mathrm{v}$, where intertwining with the weed was prevented, until 150 DAT. At 180 DAT, the sugarcane plants in the treatment iii had the same height as the plants from treatment iv (both intertwined with morning glory) and were significantly shorter $(43.1 \%)$ than the 


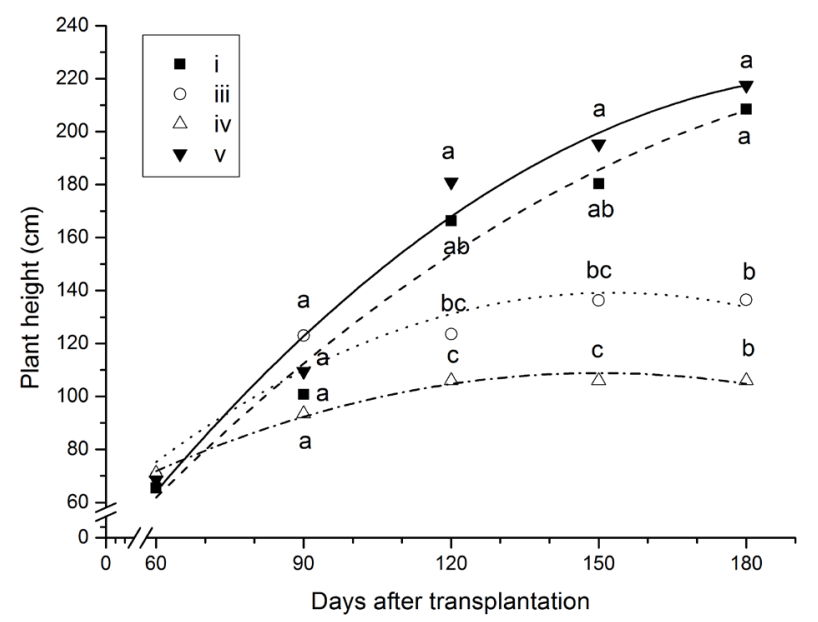

Figure 2 - Intercropping effects on sugarcane plant height: (i) sugarcane monocropping, iii) sugarcane cropping intertwined with morning glory but in separate boxes, (iv) sugarcane cropping intertwined with morning glory in attached boxes and (v) sugarcane intercropping with morning glory in attached boxes without intertwining with the sugarcane. Means followed by the same letter in each period are not different from one another at $5 \%$ probability according to Tukey's test.

control plants and plants without intertwining. For the stalk diameters, the plants from the treatments iii and $\mathrm{v}$ showed an intermediate performance that did not differ from the control plants or the plants that grew intertwined with the morning glory and shared the substrate (treatment iv).

The following absolute height and stalk diameter growth rates of the sugarcane plants were recorded during the period from 60 to 180 DAT, respectively: $1.19 \mathrm{~cm} \mathrm{day}^{-1}$ and $0.075 \mathrm{~mm}^{-1 a y}{ }^{-1}$ in the control plants, $0.55 \mathrm{~cm}^{-1 a y}{ }^{-1}$ and $0.046 \mathrm{~mm}^{-1 a y}$ ${ }^{1}$ in the plants intertwined with morning glory but in separate boxes (i.e., shoot interference), $0.29 \mathrm{~cm}$ day $^{-1}$ and $0.049 \mathrm{~mm}^{-1 a y}{ }^{-1}$ in the plants intertwined with morning glory in attached boxes (i.e., with root and shoot interference), and $1.24 \mathrm{~cm} \mathrm{day}^{-1}$ and $0.042 \mathrm{~cm} \mathrm{day}^{-1}$ in the plants intercropped with morning glory in attached boxes without weed intertwining, i.e., only with root interference. The absolute growth rate provides an estimate of the average speed of plant growth throughout the growth cycle (Campos et al. 2012).

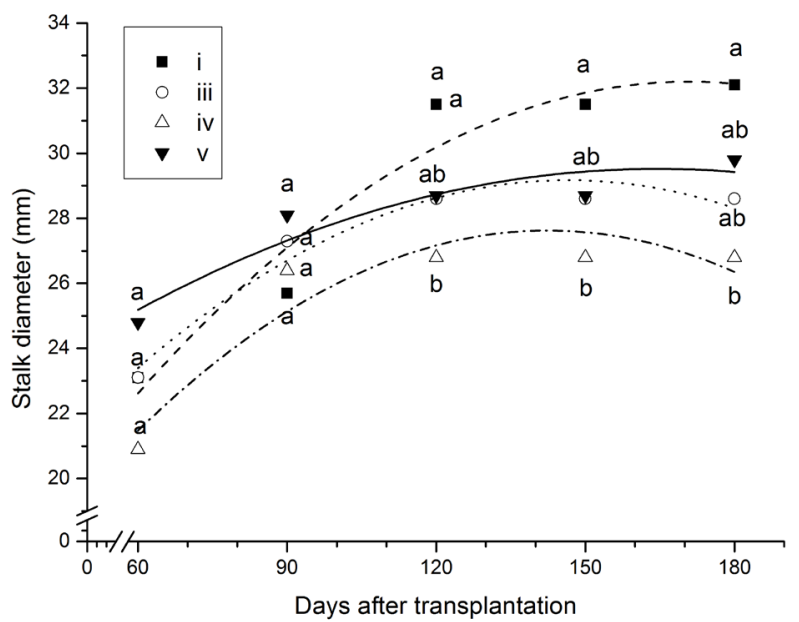

Figure 3 - Intercropping effects on the stalk diameter of sugarcane plants: (i) sugarcane monocropping, iii) sugarcane cropping intertwined with morning glory but in separate boxes, (iv) sugarcane cropping intertwined with morning glory in attached boxes and (v) sugarcane intercropping with morning glory in attached boxes without intertwining with the sugarcane. Means followed by the same letter in each period are not different from one another at 5\% probability according to Tukey's test.

These results demonstrate that the lower height of sugarcane plants most likely results from the physical restriction imposed by the morning glory plants because the lowest absolute growth rate and therefore reduced plant height occurred in treatments with weed intertwining, with shoot interference. The results of stalk diameter demonstrate that coexistence with morning glory (with or without intertwining) when the two plants share the same substrate reduces the growth rate, resulting in thinner stalks, due probability to competition by the resources of the substrate. Jones and Griffin (2009) studied competition between another morning glory species (Ipomoea coccinea) and sugarcane and observed a decrease in plant height and stalk diameter with the increase in the intercropping period that resulted in a $27 \%$ reduction in crop yield.

The analysis ofthe leaf area (green leaves) of the sugarcane plants at 90 DAT (Table I) showed that intertwining with morning glory regardless of substrate sharing (separate boxes or not) caused a 
$47.0 \%$ reduction compared to the control plants and plants without intertwining (treatment $\mathrm{v}$ ), which did not differ from one another. This pattern was maintained until 180 DAT and the reduction in leaf area resulting from intertwining increased until it reached a $90.4 \%$.

The absolute growth rates expressed as the leaf area of the sugarcane plants during the period from90 to 180 DAT were as follows: $0.81 \mathrm{dm}^{2}$ day ${ }^{1}$ in the control plants, $-0.52 \mathrm{dm}^{2}$ day $^{-1}$ in the plants intertwined with morning glory but in separate boxes, $-0.51 \mathrm{dm}^{2}$ day $^{-1}$ in the plants intertwined with morning glory in attached boxes, and $0.57 \mathrm{dm}^{2}$ day $^{-1}$ in the plants intercropped with morning glory in attached boxes without weed intercropping.

These results demonstrated that intertwining with the morning glory until 90 DAT reduced sugarcane leaf emergence and/or expansion. The intertwining effect increased until 180 DAT and even caused leaf death because the absolute growth rate expressed as the green leaf area during the period was negative (data not show).

The comparison between the stalk dry mass (STDM) means at 90 DAT (Table I) showed that sugarcane plants intercropped and intertwined with morning glory in attached boxes (treatment iv) had lower STDMs than the control plants and plants with no intertwining withmorning glory (treatment v). No differences were detected compared to the sugarcane plants intercropped and intertwined withmorning glory butin separate boxes (treatment iii), which did not differ from the control. At this time point, the reduction in the STDMs of the sugarcane plants intertwined with morning glory (treatments iii and iv) was $61.4 \%$ compared with the plants with no weed intertwining (treatment $v$ ). The results were virtually repeated in the evaluation performed at 180 DAT when this reduction reached $86.6 \%$. This result demonstrates that the adverse effect of intertwining with morning glory increased over time. The following absolute growth rates of sugarcane plants expressed as STDM were recorded during the period from 90 to 180 DAT: $14.75 \mathrm{~g} \mathrm{day}^{-1}$ in the control plants, $-0.63 \mathrm{~g} \mathrm{day}^{-1}$ in the plants intertwined with morning glory but in separate boxes, $0.10 \mathrm{~g}$ day $^{-1}$ in the plants intertwined with morning glory in attached boxes, and $9.71 \mathrm{~g}$ day $^{-1}$ in the plants intercropped with morning glory in attached boxes without weed intertwining.

A sharp reduction in the leaf area of the sugarcane plants occurred at 90 DAT, which most likely reduced their photosynthetic rate. As a consequence, there was decreased sucrose production and accumulation in the stalks of the sugarcane plants intertwined with the morning glory, resulting in a decreased dry mass and even a decreased stalk diameter when the intertwining occurred in both plants sharing the substrate. Morning glory development occurs during the phase of greatest sugarcane growth in fields. Adult plants intertwine with the stalks and leaves, thereby adversely affecting plant growth (Piza et al. 2016, Silva et al. 2009). When morning glory plants emerge after the tillering phase, the adverse effect is also generated by competition; however, the stems rapidly intertwine with the sugarcane stalk and impair light absorption when they reach the apex of the sugarcane plants, thereby decreasing photosynthesis and sucrose formation (Azania et al. 2011).

The analysis of leaf dry mass (LDM) showed a pattern similar to the pattern reported for the stalk dry mass (Table I). At 90 DAT, sugarcane plants intercropped with morning glory regardless of substrate sharing (treatments iii and iv) had a LDM that was $57.6 \%$ lower than that of the control plants (treatment i) and plants without weed intertwining (treatment $\mathrm{v}$ ), which did not differ from one another. This pattern was maintained until 180 DAT, although the adverse effect of intertwining increased and reached a $75.2 \%$ of reduction. The following absolute growth rates of sugarcane plants expressed as LDMwere recorded during the period from 90 to 180 DAT: $3.53 \mathrm{~g} \mathrm{day}^{-1}$ in the 
control plants, $0.60 \mathrm{~g} \mathrm{day}^{-1}$ in the plants intertwined with morning glory but in separate boxes, $0.55 \mathrm{~g}$ day $^{-1}$ in the plants intertwined with morning glory in attached boxes, and $3.10 \mathrm{~g} \mathrm{day}^{-1}$ in the plants intercropped with morning glory in attached boxes without weed intertwining.

The leaf dry mass results demonstrated that intertwining of sugarcane with the morning glory regardless of substrate sharing reduced sugarcane leaf emission and expansion. This effect increased with the time of intercropping, resulting in an $83 \%$ reduction in the absolute growth rate expressed as the mass during the period evaluated.

In the present study, the effect of the morning glory plants on the set of characteristics evaluated in the sugarcane plants apparently resulted more from the physical effects of choking and shading than possible competition for nutrients and water because the plants subjected to treatment $\mathrm{v}$ (sugarcane intercropping withmorning glory inattached boxeswithoutweed intertwining with the sugarcane) showed results similar to the control plants.

The leaf area and shoot dry mass (SDM) of the morning glory plants did not differ significantly among treatments at 90 DAT, demonstrating that until that time point, intercropping with the sugarcane had no effect on these characteristics (Table II); however, the differences were significant at 180 DAT. At 180 DAT, the morning glory plants that grew intertwined withthe sugarcane in attached boxes and shared the substrate (treatment iv) had $61.3 \%$ less leaf areas and $57.9 \%$ less SDM than the plants that did not intertwine with the sugarcane (treatment v). These plants of treatment iv did not differ from the plants that intertwined in separate boxes (treatment iii) or the control plants. The SDM accumulation in treatment iii plants did not differ from the control plants, although these plants accumulated $38.3 \%$ less SDM than the plants that did not intertwine with sugarcane but shared the substrate.
The following absolute growth rates of morning glory plants, expressed as leaf area and SDM, were recorded during the period from 90 to 180 DAT, respectively: $60 \mathrm{dm}^{2}$ day $^{-1}$ and $24.2 \mathrm{~g}$ day $^{-1}$ in the control plants, $57.7 \mathrm{dm}^{2}$ day $^{-1}$ and 18.3 $\mathrm{g} \mathrm{day}^{-1}$ in the plants intertwined in sugarcane but in separate boxes, $23.4 \mathrm{dm}^{2}$ day $^{-1}$ and $8.3 \mathrm{~g}_{\text {day }}{ }^{-1}$ in the plants intertwined in sugarcane in attached boxes, and $80.1 \mathrm{dm}^{2}$ day $^{-1}$ and $30.3 \mathrm{~g} \mathrm{day}^{-1}$ in the plants intercropped with sugarcane in attached boxes without intertwining. Campos et al. (2012) analyzed the growth of $M$. cissoides in pots and observed leaf area stabilization at $10.0 \mathrm{dm}^{2} 100$ days after sowing, when SDM start tostabilized, after the absolute growth ratereached $0.8 \mathrm{~g} \mathrm{day}^{-1}$ at 90 days after sowing. These values are much lower than the value found in the present study at 90 DAT, which may be attributed to the different growth conditions. Martins et al. (2010) observed that the dry matter accumulation in Merremia aegyptia (another morning glory species of the same genus) peaked 155 days after emergence (166.85 g plant $\left.^{-1}\right)$ and decreased thereafter. Campos et al. (2012) reported that the life cycle of morning glories was longer than the life cycles of annual crops, which caused problems in harvests and indirect losses if left uncontrolled; this phenomenon may occur during sugarcane development.

The results demonstrated that intercropping the morning glory with sugarcane caused a decrease in the weed leaf area when the morning glory was allowed to intertwine and share the substrate with sugarcane, culminating in the lowest absolute growth rate (expressed as the leaf area and dry mass) and therefore the lowest shoot dry mass accumulation at 180 DAT. This result may be attributed to the more intense competition for light and nutrients under that condition, whereas intertwining with the sugarcane plants (as occurred in treatment iii) resulted in the morning glory prevailing in the light competition with the sugarcane. 
TABLE I

Leaf area (LA) and leaf (LDM) and stalk (STDM) dry matter of sugarcane plants under different intercropping conditions with morning glory plants evaluated at 90 and 180 days after transplantation (DAT).

\begin{tabular}{|c|c|c|c|c|c|c|c|c|c|c|c|c|}
\hline \multirow{3}{*}{$\begin{array}{l}\text { Treatment } \\
\text { (i) }\end{array}$} & \multicolumn{6}{|c|}{90 DAT } & \multicolumn{6}{|c|}{180 DAT } \\
\hline & \multicolumn{2}{|c|}{$\begin{array}{c}\text { LA } \\
\left(\mathbf{d m}^{2}\right)\end{array}$} & \multicolumn{2}{|c|}{$\begin{array}{c}\text { STDM } \\
\text { (g) }\end{array}$} & \multicolumn{2}{|c|}{$\begin{array}{c}\text { LDM } \\
\text { (g) }\end{array}$} & \multicolumn{2}{|c|}{$\begin{array}{c}\text { LA } \\
\left(\mathbf{d m}^{2}\right)\end{array}$} & \multicolumn{2}{|c|}{$\begin{array}{c}\text { STDM } \\
\text { (g) }\end{array}$} & \multicolumn{2}{|c|}{$\begin{array}{c}\text { LDM } \\
\text { (g) }\end{array}$} \\
\hline & 121.6 & $\mathrm{a}$ & 367.9 & $a b$ & 170.2 & $\mathrm{a}$ & 195.3 & $\mathrm{a}$ & 1.695 .1 & $\mathrm{a}$ & 593.6 & $\mathrm{a}$ \\
\hline (iii) & 66.2 & $\mathrm{~b}$ & 204.6 & $\mathrm{bc}$ & 86.2 & $\mathrm{~b}$ & 19.4 & $\mathrm{~b}$ & 261.7 & $\mathrm{~b}$ & 154.5 & $\mathrm{~b}$ \\
\hline (iv) & 61.7 & $\mathrm{~b}$ & 132.2 & $\mathrm{c}$ & 73.7 & $\mathrm{~b}$ & 15.4 & $\mathrm{~b}$ & 141.0 & $\mathrm{~b}$ & 140.2 & $\mathrm{~b}$ \\
\hline (v) & 116.5 & $\mathrm{a}$ & 436.8 & $\mathrm{a}$ & 206.8 & $\mathrm{a}$ & 167.6 & $\mathrm{a}$ & 1.310 .4 & $\mathrm{a}$ & 459.1 & $\mathrm{a}$ \\
\hline $\mathbf{F}_{\text {treat }}$ & $4.3 *$ & & $11.8^{* *}$ & & $12.2 * *$ & & $50.9 * *$ & & $40.8 * *$ & & $20.8^{* *}$ & \\
\hline CV (\%) & 33.78 & & 28.80 & & 27.54 & & 26.89 & & 28.26 & & 29.39 & \\
\hline LSD & 64.9 & & 172.60 & & 77.64 & & 56.1 & & 505.63 & & 207.91 & \\
\hline
\end{tabular}

Means followed by different letters in the columns differ from one another according to Tukey's test at $5 \%$ probability. *,** Significant at 5 and $1 \%$ probability according to the F test, respectively. (i) Sugarcane monocropping, (iii) sugarcane cropping intertwined with morning glory but in separate boxes, (iv) sugarcane cropping intertwined with morning glory in attached boxes and (v) sugarcane intercropping with morning glory in attached boxes without intertwining with the sugarcane.

\section{TABLE II}

Leaf area (LA) and shoot dry mass (SDM) of morning glory plants under the different intercropping conditions with sugarcane plants evaluated at 90 and 180 days after transplantation (DAT).

\begin{tabular}{|c|c|c|c|c|c|c|c|c|}
\hline \multirow{3}{*}{$\begin{array}{c}\text { Treatment } \\
\text { (ii) }\end{array}$} & \multicolumn{4}{|c|}{90 DAT } & \multicolumn{4}{|c|}{180 DAT } \\
\hline & \multirow{2}{*}{$\begin{array}{c}\mathbf{L A}\left(\mathbf{d m}^{\mathbf{2}}\right) \\
1,124.0\end{array}$} & & \multicolumn{2}{|l|}{ SDM (g) } & \multirow{2}{*}{$\begin{array}{c}\mathbf{L A}\left(\mathbf{d m}^{2}\right) \\
6,522.6\end{array}$} & \multicolumn{3}{|c|}{ SDM (g) } \\
\hline & & $\mathrm{a}$ & 690.2 & $\mathrm{a}$ & & $a b$ & $2,864.5$ & $a b$ \\
\hline (iii) & 620.3 & $\mathrm{a}$ & 497.2 & $\mathrm{a}$ & $5,813.9$ & $a b$ & $2,146.1$ & $\mathrm{bc}$ \\
\hline (iv) & $1,141.4$ & $\mathrm{a}$ & 586.9 & $\mathrm{a}$ & $3,246.9$ & $\mathrm{~b}$ & $1,334.1$ & $\mathrm{c}$ \\
\hline (v) & $1,183.4$ & $\mathrm{a}$ & 749.2 & $\mathrm{a}$ & $8,392.6$ & $\mathrm{a}$ & $3,476.1$ & $\mathrm{a}$ \\
\hline $\mathbf{F}_{\text {treat }}$ & $1.44^{\mathrm{ns}}$ & & $1.06^{\mathrm{ns}}$ & & $4.34^{*}$ & & $8.54 * *$ & \\
\hline CV $(\%)$ & 43.55 & & 34.34 & & 34.10 & & 25.77 & \\
\hline LSD & 930.5 & & 454.98 & & $4,292.9$ & & $1,328.66$ & \\
\hline
\end{tabular}

Means followed by different letters in columns differ from one another according to Tukey's test at 5\% probability. *, ** Significant at 5 and $1 \%$ probability according to the F test, respectively. ${ }^{\mathrm{ns}}$ Non-significant according to the F test. (ii) Morning glory monocropping (iii) sugarcane cropping intertwined with morning glory but in separate boxes, (iv) sugarcane cropping intertwined with morning glory but in attached boxes and (v) sugarcane intercropping with morning glory in attached boxes without intertwining with the sugarcane.

The biological characteristic of initial growth may impart high or low interspecific competitiveness of a species with in agricultural fields. This is especially true for sugarcane, where slow initial growth was observed for M. cissoides (Campos et al. 2012). In the present study, the adverse effect of morning glory on the growth characteristics of sugarcane became significant starting 90 days after intercropping, whereas the adverse effect of sugarcane on the weed was observed at 180 days, near the end of the plant cycle (Kissmann and Groth 1999).

\section{CONCLUSIONS}

In conclusion, morning glory (Merremia cissoides) adversely affects the initial growth of RB 966928 sugarcane starting 90 days after intercropping. This effect increases with the time of intercropping and 
is primarily due to the weed intertwining with the sugarcane plants, resulting in a physical choking and shading effect. This negative effect of morning glory on sugarcane increases when the two species share the same substrate and can also adversely affect weed growth. The leaf area and the stalk and leaf dry mass of sugarcane are the characteristics more sensitive to the weed interference. Thus, both the shoot and root of $M$. cissoides interferes negatively in the growth of sugarcane, with the effect proportional to the period of coexistence, highlighting the detrimental effect on the stem (greater economic interest), and may also compromisethe mechanical harvesting of the crop.

\section{ACKNOWLEDGMENTS}

The authors would like to thank the Fundação de Amparo à Pesquisa do Estado de São Paulo (FAPESP) and Conselho Nacional de Desenvolvimento Científico e Tecnológico (CNPq) for their financial support by the scholarships to the first (Proc. $n^{\circ}$ 2013/14842-3) and last (Proc. $n^{\circ}$ 311281/2013-3) authors, respectively.

\section{REFERENCES}

AZANIA CAM, HIRATA ACS AND AZANIA AAPM. 2011. Biologia e manejo químico de corda-de-viola em canade-açúcar. Campinas: Instituto Agronômico, 12 p. (Série Tecnologia APTA. Boletim Técnico IAC, 209).

BENINCASA MMP. 2004. Análise de crescimento de plantas: noções básicas. Jaboticabal: FUNEP, 42 p.

CAMPOS LHF, MELLO MSC, CARVALHO SJP, NICOLAI MAND CHRISTOFFOLETI PJ. 2012. Crescimento inicial de Merremia cissoides, Neonotonia wightii e Stizolobium aterrimum. Planta Daninha 30: 497-504.

CONAB - COMPANHIA NACIONAL DE ABASTECIMENTO. Levantamento de Safra. 2015. Disponível em <http://www.conab.gov.br/conteudos. $\mathrm{php} ? \mathrm{a}=1253 \& \mathrm{t}=2>$. Acesso em: 11 Julho de 2015.

FERREIRA PPA AND MIOTTO STS. 2013. O gênero Merremia (Convolvulaceae) na região sul do Brasil. Rodriguésia 64: 635-646.
FERREIRA RV, CONTATO ED, KUVA MA, FERRAUDO AS, ALVES PLCA, MAGARIO FB AND SALGADO TP. 2011. Organização das comunidades infestantes de plantas daninhas na cultura da cana-de-açúcar em agrupamentospadrão. Planta Daninha 29: 363-371.

JONES CA AND GRIFFIN JL. 2009. Red morninglory (Ipomoea coccinea) control and competition in sugarcane. J Am Soc Sugar Cane Technol 29: 25-35.

KISSMANN K AND GROTH D. 1999. Plantas infestantes e nocivas, $2^{\mathrm{a}}$ ed., São Paulo: BASF. Tomo II, 978 p.

KUVA MA, FERRAUDO AS, PITELLI RA, ALVES PLCA AND SALGADO TP. 2008. Padrões de infestação de comunidades de plantas daninhas no agroecossistema de cana-crua. Planta Daninha 26: 549-557.

LUCIO FR, PARREIRA MC, PEREIRA FCM AND ALVES PLCA. 2011. Controle de convolvuláceas infestantes na cultura da cana-de-açúcar. Rev Bras Herb 109: 305-311.

MARTINELLI CA, ULIAN IZ, SIMÕES OS, PINOTTI EB, GIROTTO M, FELIPE ALS, JUNIOR CEI, SILVA DP AND BOSQUÊ GG. 2011. Interferência de plantas daninhas na cultura da cana-de-açúcar e algumas práticas de controle. Rev Cient Eletr Agron 20.

MARTINS TA, CARVALHO LB, BIANCOMSAND BIANCO S. 2010. Acúmulo de matéria seca e macronutrientes por plantas de Merremia aegyptia. Planta Daninha 28: $1023-$ 1029.

PERIM L, TOLEDO REB, NEGRISOLI E, CORRÊA MR, CARBONARI CA, ROSSI CVS AND VELINI ED. 2009. Eficácia do herbicida amicarbazone no controle em pós-emergência de espécies de corda-de-viola (Ipomoea grandifolia e Merremia cissoides). Rev Bras Herb 8: 1926.

PITELLI RA. 1985. Interferência de plantas daninhas em culturas agrícolas. Inf Agrop 120: 16-27.

PIZA CST, NEPOMUCENO MP AND ALVES PLCA. 2016. Period prior to interference of morning glory in sugarcane. Científica 44: 543-548.

RAIMÚNDEZ-URRUTIA E, AVENDAÑO L AND VELÁZQUEZ D. 2008. Reproductive biology of the morning glory Merremia macrocalyx (Ruiz \&Pavon) O’Donnell (Convolvulaceae). J Torrey Bot Soc 135: 299308.

SILVA IAB, KUVA MA, ALVES PLCA AND SALGADO TP. 2009. Interferência de uma comunidade de plantas daninhas com predominância de Ipomoea hederifolia na cana-soca. Planta Daninha 27: 265-272.

WILSON RG. 2005. Response of dry bean and weeds to fomesafen and fomesafen tank mixtures. Weed Technol 19: 201-206. 